\title{
Mental Health Status of Government and Non-Government Institutionalized Children-A Comparative Study
}

\author{
K. Shubhasri Devi, L. Uma Devi and G. Amruta Gonal* \\ Department of Human Development and Family Studies, College of Home Science, Acharya \\ N.G. Ranga Agricultural University, Guntur, AP, India \\ *Corresponding author
}

\section{A B S T R A C T}

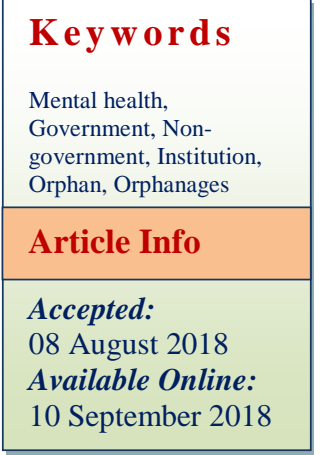

Mental health is important for individuals, especially children. The importance of healthy mental and physical development for children cannot be overemphasized. The consequences of poor mental health in childhood extend into adulthood, increasing the likelihood of low educational achievement, criminality and violence, adult mental disorder, unhealthy lifestyles and the risk of ill health. The present study was carried out in Guntur district of Andhra Pradesh to study the Mental Health Status of institutionalized children. The sample comprised of 60 children (30 Government institution children and 30 NonGovernment institution children). The sample was collected from the Government and Non- Government institutions by using purposive sampling. Mental health of institutionalized children was studied by using Mental Health Battery (MHB) developed by Arun Kumar Singh and Alpana Sen Gupta (2000). Certain statistical techniques like Mean, S.D and Z-value were used to analyze the data. The result confirms that there is significant mean difference between Government and Non-Government institutional children on their mental health.

\section{Introduction}

Children are national assets. In India children constitute 39 per cent of the country's population (Census, 2010 - 2011) which are recognized by policy-makers as a supreme national investment. Children deserve the best for their survival, good heath, development opportunity, security and dignity. A large number of children in the country are in institutional care. All children in need of care and protection are vulnerable, as their needs are more acute. Large populations of children in the country are also exposed to difficult circumstances. Mental health is a level of psychological well-being; it is the psychological state of someone who is functioning at a satisfactory level of emotional and behavioral adjustment. From the perspective of positive psychology or holism, mental health may include an individual's ability to enjoy life, and create a balance between life activities and efforts to achieve psychological resilience. According to World Health Organization (WHO) mental health is a state of well-being in which the individual 
realizes his or her own abilities, can cope with the normal stresses of life, can work productively and fruitfully, and is able to make a contribution to his or her community.

Many studies revealed that children in institutions experience psycho social issues like loss of trust and feeling of insecurity and other socio emotional problems. Mental health disorders are a serious public health concern and are likely to interfere with individual's mental and physical wellbeing. Specifically among children mental health issues may interfere growth, attainment of educational goals and acquisition of basic life skills, which may have adverse consequences and impair overall development.

Mental health is not just the absence of mental illness. Mental health includes our emotional, psychological, and social well-being. It affects how we think, feel, and act. It also helps determine how we handle stress, relate to others, and make choices. Mental health is important at every stage of life, from childhood and adolescence through adulthood.

\section{Materials and Methods}

The Sample consists of 60 girl children between the age group of 10-15 and those who were staying in Government (30) and NonGovernment (30) institutions. Sample was selected from Guntur district of Andhra Pradesh. Institutionalized children were selected purposively for the study.

The Mental Health Status of the institutionalized children was measured using Mental Health Battery (Arun Kumar Singh and AlpanaSen Gupta, 2000). This scale consists of 130 statements; each statement is in "Yes or No" form.

The scale has two sections A and B. Section-A collects the information related the socio economic status of the family and section-B with other dimensions like emotional stability, over all adjustment, autonomy, security insecurity, self-concept and intelligence. The data was collected from the sample and scoring was done. Based on the scores obtained the children were categorized as High, Average and Low for the dimensions of mental health. And for the overall Mental Health Status the categorization was Excellent Mental Health, Good Mental Health, Average Mental Health, Poor Mental Health and Very Poor Mental Health.

Bhat et al., (2015) in their study reported institutionalized adolescents experiencing many mental health related problems leading to negative consequences in later life.

Hadush (2015) study revealed that there was a significant difference between institutionalized and Non institutionalized children in their level of depression and also revealed that Non- institutionalized children obtained high scores on self -esteem scale than institutionalized orphan children.

Saraswati et al., (2008) results revealed that majority of institutional children had unsatisfactory adjustment indicating more problems in social, emotional and educational areas. These children were emotionally unstable, impatient, demanding, disobedient, less accommodating, shy, timid, sensitive, insecure, aggressive, worried, troubling, lack concentration and interest in studies, poor memory which put impediment in their adjustment in the institutional living and in effective utilization of its services.

Tadesse et al., (2014) revealed that orphan vulnerable children in the institutions accessed all the basic services necessary to sustain their lives but these institutions lack in providing good environment for psychosocial development for the good mental health and 
children suffer from many multidimensional psychosocial problems.

The data was analysed through using Mean, standard deviation and $\mathrm{Z}$ test.

\section{Results and Discussion}

\section{Dimensions of mental health}

\section{Section-A}

\section{Socio-economic status (SES)}

The results of the study showed that majority of the children both from Government $(73 \%)$ and Non-Government (80\%) were found to be in low SES. It is known fact that only the children from lower financial background have taken admissions in the residential institutions run by Government and charitable Trusts. This might be because their parents were unable to bear their educational and other expenses. Interestingly 27 percent and 20 per cent of the children were in middle SES in both Government and Non -Government institutions respectively.

\section{Section-B}

This section deals with results on 6 dimensions of Mental Health and total Mental Health Status.

\section{Emotional stability}

Is experiencing subjective stable feelings which have positive or negative values for the individual. Only 7 per cent of the children residing in Non-Government institution were in high Emotional stability. Whereas, none from Government institution found to have the high mental stability. It is interesting to know that most of the children (80\%) from the NonGovernment institution had the average emotional stability and very few (13\%) of them had poor or below average mental stability. In case of children residing at Government institution 57 per cent of them had the average emotional stability and 43 per cent of them were low

\section{Overall adjustment}

Overall adjustment of the Government (80\%) and Non-Government $(60 \%)$ institution children was found high. They had well adjusted to the hostel environment, health, social, emotional and school on one hand and cognition on the other. Twenty per cent and forty per cent of the Government and NonGovernment institutionalized children were found to be average respectively and interestingly none of them had poor adjustment with the environment and other social aspects.

\section{Autonomy}

It is a stage of independence of selfdetermination in thinking. It is clearly observed from the table 1 that NonGovernment institution children's perceptions about autonomy were equally distributed between average and high (50\%). Sixty percent of children in Government institution were fallen under average and remaining 40 per cent of the sample under below average category in dimension of autonomy. The results showed that Non-Government institution children had better autonomy than the children residing in Government institution.

\section{Security and insecurity}

It refers to a high or low sense of safety, confidence, freedom from fear, apprehension or anxiety particularly with respect to fulfilling the person's present or future needs. From table 1, we can infer that Average levels of security and insecurity dimension found in 
children residing in Government (64\%) and Non-Government institution (74\%). Interestingly one third of the Government institution children had high perception about security and insecurity dimension and one fourth of the Non-Government institutionalized children had high perception.

\section{Self-concept}

It is the sum total of the personal's attitudes and knowledge towards himself and evaluation of his/her achievements. Majority of the children had average level of self concept in both Government $(90 \%)$ and NonGovernment (87\%) institutions. Very few children had high level of self-concept in both Government (3) and Non-Government institution (3). It is surprising to know that the residents of Non-Government institution $(10 \%)$ had low levels of self -concept and none of the Government institutionalized children had low levels of self-concept. Reasons for the same should be studied.

\section{Intelligence}

It is interesting to note form the results that majority $(83 \%)$ of children exhibited average level of intelligence in Non-Government institution and remaining 17 per cent exhibited high levels of intelligence. Whereas, half of the children residing in Government institution exhibited low level of intelligence $(50 \%)$ and remaining half were of average level intelligence. It is noteworthy to mention that none of the Government institutionalized children had high level of intelligence and none of the children in Non-Government institution had low levels of intelligence.

\section{Overall mental health status}

The sum of the dimensions of section B; Emotional stability, over-all adjustment, autonomy, security-insecurity, self-concept and intelligence together called overall Mental Health Status. From the table 1 it can be said that overall Mental Health Status that nearly three-fourth of the children $(73 \%)$ from Government institution reported of having good Mental Health Status followed by 27 per cent children having average Mental Health Status. In Non-Government institution majority $(90 \%)$ of the children were fell under good mental health category followed by 7 percent under excellent mental health and remaining 3 percent were having average mental health. It is noteworthy to mention that in general children residing in both Government and Non-Government institution were having good mental health.

\section{Socio-economic status (SES)}

From table 1 it was clear that, there was no significant difference between the children of Government and Non-Government institutions, in their socioeconomic status.

\section{Emotional stability}

Emotional stability is not only one of the effective determinants of the personality patterns, but it also helps to control the growth of adolescent development. The concept of stable emotional behaviour at any level is that which reflects the fruits of the normal emotional development.

The perusal from table 2 shows the mean comparison of Government and NonGovernment institutional children on emotional stability of mental health battery. The table 2 reveals that the mean score of Non-Government institutional children is higher than the mean score of Government institutional children and the difference is significant at 5 per cent level. The NonGovernment institutional children display better emotional stability as compared to Government institutional children. Musisi et 
al., (2007) reported that more orphans compared to non-orphans exhibited common emotional and behavioral problems but no major psychiatric disorders.

\section{Over-all adjustment}

It refers to individual's achieving an overall harmonious balance between the demands of various aspects of environment, such as home, health, social emotional and school on the one hand and cognition on the other. The perusal of above table reveals that there is no significant mean difference between Government and Non-Government institutional children on over-all adjustment. The table indicates that both the groups displayed somewhat similar overall adjustment. Hamid (2012) found that that there is insignificant difference between Institutionalized and Non-institutionalized orphans on all dimensions except on overall adjustment dimension, where institutionalized orphans were found having better overall adjustment than non- institutionalized orphans.

\section{Autonomy}

It refers to a stage of independence and self determination in thinking. The results revealed that there was no significant mean difference between Government and Non-Government institutional children on autonomy component of mental health battery. The result reveals that both Government and Non- Government institutional children were more autonomous and have better independence and selfdetermination in thinking.

Study by Perez (2012) reveals that males have higher scores of Autonomy than females but there is no significant gender difference in terms of environmental mastery, personal growth and self-acceptance.

\section{Security-insecurity}

It refers to a high or low sense of safety, confidence, freedom from fear, apprehension or anxiety particularly with respect to fulfilling the persons present of future needs.

A quick look of the table 2 reveals that there was no significant mean difference between Government and Non-Government institutional children on security-insecurity component of mental health battery. The mean score favours institutionalized children which indicates that Government and NonGovernment institutional children showed better sense of safety, confidence, freedom from fear. In contrary to the present study Maqbool and Ganai (2015) who found that orphan and Non-orphan adolescents significantly differ on Security insecurity dimension. The mean difference favour the non-orphan adolescents which clearly indicates that Non-orphan adolescents had high Security/insecurity as compared to orphan adolescents.

\section{Self-concept}

It refers to the sum total of the person's attitudes and knowledge towards himself and evaluation of his achievements.

The table 2 shows the mean comparison of Government and Non-Government institutional children on self- concept dimension of mental health battery. As the mean score favours Government institutional children which indicates that Government institutional children showed better attitude, knowledge of themselves and evaluation of their achievements than the Non-Government institutional children. Ahad (2016) found significant mean difference in self-concept of male \& female adolescent orphans where male adolescent orphans were found to have higher self- concept than female adolescent orphans. 
Table.1 Mental health status of the children residing in government and non-government institution

\begin{tabular}{|c|c|c|c|c|c|}
\hline \multicolumn{2}{|c|}{ 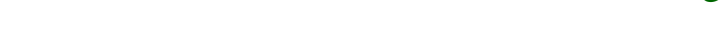 } & \multirow{2}{*}{\multicolumn{2}{|c|}{$\begin{array}{c}\text { Government } \\
\text { institution(n=30) }\end{array}$}} & \multirow{2}{*}{\multicolumn{2}{|c|}{$\begin{array}{l}\mathrm{N}=6 \mathrm{C} \\
\text { Non-Government } \\
\text { institution(n=30) }\end{array}$}} \\
\hline S. No & \multirow[t]{2}{*}{ Dimensions } & & & & \\
\hline & & No & $\%$ & No & $\%$ \\
\hline I & A. Socio-economic status (SES) & & & & \\
\hline 1. & Upper SES & 0 & $0 \%$ & 0 & $0 \%$ \\
\hline 2. & Middle SES & 8 & $27 \%$ & 6 & $20 \%$ \\
\hline 3. & Low SES & 22 & $73 \%$ & 24 & $80 \%$ \\
\hline $\mathbf{B}$ & Dimensions of Mental Health & & & & \\
\hline I. & Emotional stability & & & & \\
\hline 1. & High & 0 & $0 \%$ & 2 & $7 \%$ \\
\hline 2. & Average & 17 & $57 \%$ & 24 & $80 \%$ \\
\hline 3. & Low & 13 & $43 \%$ & 4 & $13 \%$ \\
\hline II. & Over-all adjustment & & & & \\
\hline 1. & High & 24 & $80 \%$ & 18 & $60 \%$ \\
\hline 2. & Average & 6 & $20 \%$ & 12 & $40 \%$ \\
\hline 3. & Low & 0 & $0 \%$ & 0 & $0 \%$ \\
\hline III & Autonomy & & & & \\
\hline 1. & High & 0 & $0 \%$ & 15 & $50 \%$ \\
\hline 2. & Average & 18 & $60 \%$ & 15 & $50 \%$ \\
\hline 3. & Low & 12 & $40 \%$ & 0 & $0 \%$ \\
\hline IV & Security-Insecurity & & & & \\
\hline 1. & High & 10 & $33 \%$ & 7 & $23 \%$ \\
\hline 2. & Average & 19 & $64 \%$ & 22 & $74 \%$ \\
\hline 3. & Low & 1 & $3 \%$ & 1 & $3 \%$ \\
\hline $\mathbf{V}$ & Self-concept & & & & \\
\hline 1. & High & 3 & $10 \%$ & 1 & $3 \%$ \\
\hline 2. & Average & 27 & $90 \%$ & 26 & $87 \%$ \\
\hline 3. & Low & 0 & $0 \%$ & 3 & $10 \%$ \\
\hline VI & Intelligence & & & & \\
\hline 1. & High & 0 & $0 \%$ & 5 & $17 \%$ \\
\hline 2. & Average & 15 & $50 \%$ & 25 & $83 \%$ \\
\hline 3. & Low & 15 & $50 \%$ & 0 & $0 \%$ \\
\hline & Total Mental Health Status & & & & \\
\hline 1. & Excellent Mental Health & 0 & $0 \%$ & 2 & $7 \%$ \\
\hline 2. & Good Mental Health & 22 & $73 \%$ & 27 & $90 \%$ \\
\hline 3. & Average Mental Health & 8 & $27 \%$ & 1 & $3 \%$ \\
\hline 4. & Poor Mental Health & 0 & $0 \%$ & 0 & $0 \%$ \\
\hline 5. & Very Poor Mental Health & 0 & $0 \%$ & 0 & $0 \%$ \\
\hline
\end{tabular}


Table.2 Mean differences in mental health status of government and non-government institutionalized children

\begin{tabular}{|c|c|c|c|c|c|c|}
\hline \multirow[t]{2}{*}{ S.no } & \multirow[t]{2}{*}{$\begin{array}{c}\text { Dimensions of Mental } \\
\text { Health Status }\end{array}$} & \multicolumn{2}{|c|}{$\begin{array}{c}\text { Government } \\
\text { institution }(\mathrm{n}=\mathbf{3 0})\end{array}$} & \multicolumn{3}{|c|}{$\begin{array}{l}\text { Non-Government institution } \\
\qquad(\mathrm{n}=\mathbf{3 0})\end{array}$} \\
\hline & & Mean & SD & Mean & SD & 'Z' Value \\
\hline $\mathbf{I}$ & Section-A & & & & & \\
\hline 1. & Socio-Economic status & 8.0667 & 1.22990 & 8.2333 & 1.38174 & 0.493 \\
\hline II & Section-B & & & & & \\
\hline 1. & Emotional Stability & 5.8000 & 1.34933 & 7.9667 & 1.73172 & $5.405^{*}$ \\
\hline 2. & Over-all adjustment & 28.3667 & 2.47028 & 27.2667 & 2.55874 & 1.694 \\
\hline 3. & Autonomy & 10.4333 & .85836 & 10.7000 & 1.17884 & 1.002 \\
\hline 4. & Security-Insecurity & 9.9000 & 2.29467 & 9.5000 & 1.87083 & 0.74 \\
\hline 5. & Self-concept & 8.7333 & 1.31131 & 7.3667 & 1.49674 & $3.761 *$ \\
\hline 6. & Intelligence & 10.7333 & 2.71564 & 16.7000 & 3.72457 & $7.09 *$ \\
\hline & Total Mental Health Status & 168.2000 & 6.95998 & 183.2333 & 10.52643 & $6.52498 *$ \\
\hline
\end{tabular}

*Significant at $5 \%$ level

\section{Intelligence}

It refers to general mental ability which helps the person in thinking rationally, and in behaving purposefully in his environment.

A quick glance on the table 2 reveals that there was a significant mean difference between the two groups of children on intelligence component of mental health battery and difference was found to be significant at 5 per cent level. The mean score favours Non-Government institutional children which indicate that Non-Government institutional children showed better sense of safety, confidence, freedom from fear than the Government institutional children.

\section{Overall mental health status}

The perusal of table 2 shows the mean difference of Government and NonGovernment institutional children on overall dimensions of mental health battery. The above table reveals that there was significant mean difference between Government and Non-Government institutional children on overall dimension of mental health and the difference is 5 per cent level. As the mean score favours Non-Government institutional children which indicates that NonGovernment institutional children displayed better mental health than the Government institutional children.

Whetten et al., (2009) studied a comparison of the Wellbeing of Orphans and Abandoned Children Ages 6-12 in Institutional and Community-Based Care Settings in 5 Less Wealthy Nations and revealed that Orphans and Abandoned Children's health, emotional and cognitive functioning and physical growth were better than children reared in community based care settings.

The present study focused on difference of Mental Health Status of Government and Non-Government institutionalized Children. There are a many of factors that can impact a child's Mental Health Status, both positively and negatively. Providing children with an environment that provides independence, social and emotional stability, secured and protected environment love, compassion, trust, and understanding will greatly impact a child so that they can build on these stepping 
stones to have a productive lifestyle. Many children especially institutionalized children don't receive that type of lifestyle. There was a significant difference between Government and Non-Government institutionalized children in three dimensions of mental health like emotional stability, self-concept and Intelligence. Emotional stability and intelligence of the Non-Government institution found high than the Government institution. It is amazing to know that Selfconcept of Government institutionalized children was high compared with nonGovernment institution. It was found that there was no significant difference between Government and Non-Government institutionalized children in terms of over-all adjustment, autonomy and SecurityInsecurity. Finally it was concluded that there was a significant difference between Government institution and Non- Government institution children in terms of over -all Mental Health Status. Overall Mental Health Status of children of Non-Government was found good compared to Government institution. The results were favourable towards the Non-Government institution because the environment and the care taken by the Non-Government institution were good compared to Government institution.

In order to improve mental health and wellbeing of institutionalized children more psycho social support should be provided along with the opportunities available to the children for physical needs. The staff should have the training to address the psychological needs of children. The caregivers can also help institutionalized children to promote sound mental health among institutionalized children.

\section{Acknowledgements}

My sincere gratitude to the chairperson and children and staff of the Kasturba Gandhi
Government institute, Sattenpalli and Chinmaya Vijaya Non- Government Institute, Kaza villge, Guntur district who gave me the permission and co-operated for conducting research.

I am greatly indebted to Statistician Dr. Kiran Prakash, Dept. of Statistics, Advanced Post Graduate Centre, ANGRAU, Lam, Guntur for helping me in statistical analysis of the data and helped for successful completion of my research work.

My sincere thanks to the entire staff of College of Home Science, Guntur for providing all the facilities in completion of my research work. I would like to express my whole hearted thanks to Acharya N.G. Ranga Agricultural University (ANGRAU)

\section{References}

Ahad, R., Ara, S and Shah, S.A. SelfConcept and Aggression among Institutionalize orphans of Kashmir. The international Journal of Indian psychology. 2016, 3(2):104-116.

Bhat, A.A., Rahman, S and Bhat, N.M. Mental Health Issues in Institutionalized Adolescent Orphans. The International Journal of Indian Psychology. 2015, 3(1): 57-76.

Census of India 2010-11. http://www. childlineindia.org.in/child-in-india.htm.

Hadush, E. The Level of Depression and Self Esteem among Institutionalized and Non-Institutionalized Orphan Children. School of Psychology. 2015, 1-96.

Hamid, N. Mental health, emotional state and coping strategies: a study of orphans of Kashmir valley. 2012, 1-176. https://ndl.iitkgp.ac.in/document/97jJQxPrXR0f3d7thOjnQm-GNe89tm9pR. Maqbool, A and Ganai, M.Y. A study of selfconcept, mental health and academic achievement of orphan and Non-orphan 
adolescents. Diplomica Publishing GmbH, 2015, https://www.anchorpublishing.com/document/320315.1-30.

Musisi, S., Kinyanda, E., Nakasujja, $\mathrm{N}$ and Nakigudde, J.A comparison of the behavioral and emotional disorders of primary school-going orphans and nonorphans in Uganda. African Health Sciences. 2007, 7(4): 202-213.

Perez, J.A. Gender Difference in Psychological Well-being among Filipino College Student Samples. International Journal of Humanities and Social Science. 2012, 2(13):84-93.

Saraswati, C., Hunshal and Gaonkar, V. A study on adjustment of institutionalized children. Karnataka Journal of Agricultural Sciences. 2008, 21(4): 548552.

Singh, A.K and Gupta, A.S. Mental Health Battery. National Psychological
Corporation, 4/230, KacheriGhat, Agra. 2000, 1-12.

Tadesse, S., Dereje, F and Belay, M. Psychosocial wellbeing of Orphan and Vulnerable Children at Orphanages in Gondar Town, North West Ethiopia. Journal of Public Epidemiology. 2014, 6(10): 293-301.

Whetten, K., Ostermann, J., Whetten, R.A., Pence, B.W., O'Donnell, K., Messer, L.C., Thielman, N.M and the Positive Outcomes for Orphans (POFO) Research Team. A Comparison of the Wellbeing of Orphans and Abandoned Children Ages 6-12 in Institutional and Community-Based Care Settings in 5 Less Wealthy Nations. PLOS ONE. 2009, 4(12): 169.

World Health Organization. 2014. http:// www.who.int/features/factfiles/mental_ health/en/

\section{How to cite this article:}

Shubhasri Devi, K., L. Uma Devi and Amruta Gonal, G. 2018. Mental Health Status of Government and Non-Government Institutionalized Children-A Comparative Study. Int.J.Curr.Microbiol.App.Sci. 7(09): 1032-1040. doi: https://doi.org/10.20546/ijcmas.2018.709.123 